\title{
Faith schools, the common good and the Muslim tradition
}

\section{Introduction}

In some of his recent writings, Professor Richard Pring has examined the contentious issue of faith schools in liberal societies (Pring 2005, 2009). Pring's interest in the justification of faith schools is articulated most explicitly in a chapter titled, Faith Schools: Can they be justified? (2005) where, after surveying arguments for and against faith schools, he concludes,

the debate, therefore, about faith schools...hinges ultimately ... upon the aims of education, the rationality of nurturing a particular set of faith based beliefs, the value of individual autonomy and the extent to which indoctrination should at all costs be avoided (p. 56).

He also outlines the way in which defenders of faith schools need to position themselves in order to articulate the aims of education so that they become consistent with rationality and autonomy; but notes that such a defence is yet to be provided.

In the chapter, Can faith schools serve the common good? Pring returns to the question of the justification of faith schools, this time providing a cautious defence for them (2009). He notes that one of the important roles of such schools in multi-cultural societies, is to contribute to the common good, a task that he did not think could be realised easily. Faith based schooling requires separateness, with education geared to preserving particular identities and sociocultural traditions. The common good requires a degree of shared experience and interactions with different kinds of pupils, a task for which common schooling seems to be well suited. It is in investigating Terence McLaughlin's attempt to reconcile faith schooling with the common good that Pring presents his own distinctive response to the issue. He observes that defenders of faith schools, such as McLaughlin and others, would argue that 'the common good is served better by those who are deeply rooted in the very best of the different traditions of the communities that make up society' (p.72). He goes on to state that acquainting children with the very best of tradition cannot be achieved through descriptive accounts of different religions, but rather, requires 'an immersion in it [tradition] and in the social practices which embody more than words can tell of the essence of the tradition' (p.74). Such an immersion, Pring 
observes, can only take place 'though the practical and reflective tradition of a school which respects them, which takes them back to their intellectual and spiritual roots and which embeds them in a social way of life through which they find expression' (p.75).

In other words, Pring suggests that it is through an education in the very best of a religious tradition that faith schools may be able to provide a defensible rationale for themselves - a rationale which promotes rationality and autonomy consistent both with the liberal tradition and with distinctive faith traditions. But, how do we define and identify the very best of a tradition? What would the education in Muslim schools look like if the schools sought to introduce children into the very best of a tradition? These are some of the questions I will explore in this chapter.

Taking Pring's defence as a springboard, and Muslim faith schools as a case study, this chapter will explore what 'the very best of a tradition' could mean in the context of Islam. The next section will provide a brief introduction to Muslim schools. This will be followed by a survey of writings on Muslim education to assess how the Muslim tradition is conceptualised and drawn upon within these works. It will be noted that Muslim thinkers differ in the ways in which they conceptualise the very best of the tradition and its relevance to education today. This observation leads to the application of an insight from religious studies that a religious tradition is not an objectified reality out there from which 'the best' can be read. Rather, like any reading of the past, what we refer to as the Muslim tradition is actually an outcome of a fusion of horizons between the historian and sources through which s/he tries to make sense of the past. The echo of a Gramscian approach will be clear here. Given the interpretive understanding of religions as described above, this chapter will then argue that a move towards the very best of a tradition would require re-conceptualising the idea of religion as an interpretive discourse, and for children to be seen as inheritors and creators of meanings rather than simply receivers of it. This will be followed by some pedagogical implications of the ideas suggested in the paper. Finally, some conclusive comments will be offered.

\section{Muslim faith schools - ideals and realities}

Though Muslims have a centuries' old presence in Britain, their concerns with education date back to the 1950s and 1960s when the temporary work force was transformed into a community, as workers were joined by their families. During the 1960s, most Muslims were agreeable for the education authorities to overcome the putative 'cultural deficit' (Ansari 2004). 
However, as time passed, a distinct Muslim consciousness emerged, which was both articulated through and reinforced by education. As noted by Ansari and others, it is in the field of education that Muslims have been most vocal, and where they get the most publicity (Ansari 2004, Fetzer 2006). As a result, there are currently more than 150 Muslim faith schools in the United Kingdom, twelve of which are state-funded.

Motivations for creating these schools were grounded in a parental and communal desire for the preservation of tradition and safeguarding of Muslim children against what was perceived as the onslaught of a western secular tide (Hewitt 1996, Khan-Cheema 1984, Sarwar 1994, Zine 2008). To this, must be added the goal of socio-economic mobility through education (Ameli, Azam, \& Merali 2005, Halstead 1995). These two aims, i.e.: cultural preservation and socio-economic mobility, are manifested in the mission statements of several Muslim schools.

There is no unanimity among Muslims about the desirability of faith schools. Though some surveys have shown that there is an increasing appetite for such schools, the fact is, that at least 95\% (and by some estimates 97\%) of over half-a-million Muslim children in the UK go to state schools, secular or Christian denominational.

With regard to exam results, many Muslim schools are doing well. Some in fact, are among the top in their boroughs. As of January 2014, Bolton Muslim Girls' School, for example, is the top state school in the borough. ${ }^{1}$ A broader assessment of Muslim schools by bringing together some of the limited research on the actual teaching and learning in Muslim schools, however, raises several concerns. We find criticisms of faith schools around indoctrination, at least with regard to religious beliefs and practices, segregation, poor quality of teaching and governance, and unsatisfactory levels of opportunities in the arts (Mustafa 1999, MacEoin 2009, Merry 2007, Zine 2011, Parker-Jenkins 2011, Panjwani 2012 \& 2014, Sahin 2013). Merry's observation that teachers in Muslim schools 'learn very quickly that Islamic schools promise many things that they cannot deliver' is generally true (Merry 2007, p 61).

To these general observations, we can add details for at least one of the traits that seems to be an important element of any contribution to the common good: helping children learn to engage

\footnotetext{
${ }^{1}$ Available at: , http://www.theboltonnews.co.uk/news/10960194.School_league_tables_Bolton_s_best_performing_schools_r evealed/ [Accessed January 15, 2015].
} 
with a plurality of ideas, doctrines and interpretations. It would thus be expected that Muslim schools would teach about other religions and about the internal diversity among Muslims.

A recent study of an admittedly small group of schools concluded that while many Muslim schools are making serious efforts to engage with religious diversity, 'much more can be done to build upon the good intentions and current efforts'. It was noted in particular that schools find intra-Muslim diversity more difficult to engage with than inter-religious diversity (Panjwani 2014).

\section{Education and the very best of Muslim tradition}

As noted earlier, Pring's cautious defence of faith schools is based on the idea that they can prepare students to contribute to the common good by inducting them in 'the very best of the different traditions', a proposal reminiscent of Arnold's definition of culture as 'the best which has been thought and said'. Though Pring does not elaborate the role of the 'very best of the different tradition', it can be speculated that he, again in line with Arnold's view on culture, thought of it to be a shield against corrosive forces of the times we live in - 'malaises of modernity', as Charles Taylor calls them (Taylor 1991). But before we ask whether or not Muslim faith schools are introducing children to the very best of Muslim tradition and thereby preparing them for a proper engagement with the issues of their time, we will need to explore what we mean by the very best of Muslim tradition.

It is widely accepted among scholars of Muslim societies that the best intellectual and cultural period of Muslim societies was in the period from the eight to thirteenth centuries (Goodman 2003, Makdisi 1990, Saliba 2011). ${ }^{2}$ Almost all Muslim reformers interested in rebuilding Muslim societies without breaking their links with the tradition have tried to investigate the nature of Muslim cultures at that time to draw inspiration and understand the factors behind a confident and thriving civilisation (Kurzman 2002, Rahman 1982).

Advocates of Islamic education too, have looked back to this period to determine the principles of education (al-Attas 1979, Rahman 1982, Nasr 1985, Ashraf 1988, al-Faruqi 1995, Cook

\footnotetext{
${ }^{2}$ There is little consensus on where this period ends, with some scholars stretching it to the $17^{\text {th }}$ century. I have referred to the five centuries only because these are accepted by almost all scholars as a period of immense intellectual and cultural effervescence.
} 
2010, Waghid 2011, Sahin 2013) and to help them create modes of rapprochements between the received Muslim traditions and modernities of their times.

An analysis of these works on Muslim education shows that a significant shift has occurred in the manner in which such education and its relationship with the Muslim past and a liberal theory of education is understood.

Writers in the 1970s and 1980s such as al-Attas, al-Faruqi, Nasr and Ashraf postulated a clear demarcation between Islamic and liberal conceptions of education. For instance, al-Attas claims:

We should know, and earnestly realise that knowledge is not truly neutral; that different cultures have their own conceptions about knowledge, even though there are similarities. There exist such profound and absolute differences between Islam and Western culture such that they cannot be reconciled (al-Attas 1979, p 19).

For them, the aim of education was 'the creation of the good and righteous man who worships Allah in the true sense of the term, builds up the structure of his earthly life according to the Sharia, and employs it to serve his faith' (Ashraf and Hussain 1979). For them, the best of Muslim tradition was to live life within the framework of God's Will, and seek to develop a full range of human capacities within this framework.

Education should aim at the balanced growth of the total personality of man through training of Man's spirit, intellect, rational self, feelings and bodily senses. The training imparted to a Muslim, must be such that faith is infused into the whole of his personality and creates in him an emotional attachment to Islam, and enables him to follow the Qur'an and Sunna, and be governed by the Islamic system of values willingly and joyfully so that he may proceed to the realisation of his status as Khalifatullah to whom Allah has promised the authority of the universe (al-Attas 1979, pp 158-159).

Submission, certainty, obedience and faith are considered to be the guiding principles of Islamic education, principles that were seen to underpin the best of the Muslim tradition in its heydays. 
More recent writings by Waghid, Sahin and others reveal a significantly different vision of Islamic education, one which can lead to a positive engagement with the liberal tradition. Waghid (2011) makes a distinction between a minimalist and maximalist conception of Islamic education. He terms the conventional rote learning and indoctrinating approach as minimalist and argues for a shift towards a maximalist model which 'occurs when views are considered in the public realm and justifiable arguments are preferred in defence of particular truth claims. This view [maximalist] also holds that no scholar has absolute jurisdiction over what counts as legitimate or not, but rather that meanings are shared, experienced and deliberated upon, on the understanding that something new or other might still emanate' (p 4).

Sahin (2013) argues that hitherto, Islamic education has been interpreted as a religious endeavour. As a result, 'Islamic education and education in general within Muslim societies across the globe has been reduced to a process of mere training, instruction, and, often if not always, indoctrination' ( $p$ 238). Through an engagement with the Islamic scared sources of the Qur'an and the prophetic tradition, Sahin proposes a new interpretation of Islamic education that is 'critical, dialogical and transformative.'

In my writings, (Panjwani 2009), I have stressed the need to develop an 'overlapping consensus' between the Islamic and liberal conceptions of education. Recent debates between liberals and communitarians have encouraged a post-communitarian liberal approach, articulated in the writings of thinkers such as Kymlicka and Taylor, which takes account of the importance of tradition and culture without giving up on the centrality of autonomy and reason. At the same time, the Muslim tradition, particularly in its strand of falsafa (philosophy) has the necessary critical, rational and agency centred intellectual resources to lead to an education system that promotes the values of inclusiveness, freedom and consistent rationality, thereby creating the possibility of an overlapping consensus between Islamic and liberal educational approaches. One of the maladies in conventional Islamic education is its stress upon certainty and a failure to distinguish between the realms of knowledge and faith, even though radical doubt and scepticism are in fact not alien to Muslim tradition; as seen in the works of al-Jahiz (d.868), al-Ghazali (d.1111) and others. ${ }^{3}$

\footnotetext{
${ }^{3}$ A good example of a critical approach to one's own tradition is provided in al-Ghazali's Munqid (al-Ghazali 1953).
} 
From this survey of writers on Islamic education, it can be noted that the interpretation of what is the very best in Muslim tradition has changed over time. Writing in the 1970s and 1980s, scholars such as al-Attas and others were shaped by a reaction to what was perceived to be an antagonistic liberal tradition. They saw individuality and questioning of received knowledge as the hallmark of western liberal education, and responded by drawing upon those elements of Muslim tradition that stressed community and certainty, making these the pillars of Islamic education. As Ashraf notes,

By denying faith and by creating a conglomeration of multiple choices...with no norm to be guided by, except reason or social values or....fashions, the secularist educationalists create an unsettled situation for children. Doubts and scepticism are preferred and even encouraged. As a result children have no norm of good and evil, right and wrong, justice and injustice, truth and falsehood (Ashraf 1987, p 11).

There are many who continue to follow these writers, including al-Attas in particular, but there are now new conceptions of Islamic education as well. More recent writings on Islamic education have distanced themselves from such antagonistic understandings and have shown recognition of the importance of scepticism, reason based argument and agency of the learner, thereby creating greater possibility of a positive engagement and an 'overlapping consensus' between the Islamic and the liberal tradition. As Sahin notes, 'Addressing this educational task requires not only engagement with the Islamic educational legacy, but also the facilitation of a critical dialogue with contemporary educational philosophies and pedagogical practices' (2013, p 238).

Why do we have such a variety of understandings of Islamic education? What implications does this variety have for Muslim schools and their contribution to the common good? We will deal with the first question here and the second in the next section.

We often hear people asking about Islam's relation to democracy or human rights. Another related question asks about Islam's teachings on gender equity. The assumption underlying such questions is that Islam is an objectified reality which has fixed and transparent answers to such questions, which can be found in authoritative and foundational texts. 
But this way of approaching religion is methodologically flawed. Even from a believers' point of view, the historicity of religious ideas and the role of human agency through the interpretation of texts and events will be hard to deny. A cursory study of Muslim history, for instance, will show how understandings of Islam have transformed over the centuries. As a result, today there is hardly anything beyond a discourse consisting of some formulaic words that is common to all Muslims. For examples, Muslims use the word tawhid, to express their belief in the unity of God, but this is where the shared space ends. The moment we seek to articulate the idea of the oneness of God, we find a wide range of understandings from highly anthropomorphic to metaphoric and from spatially located to pantheistic. Yet, this change and variety has happened with constant reference to the sacred sources, particularly the Qur'an. Whenever 'good and sufficient' reasons have been found to evolve the tradition, the poetic, open-ended and symbolic nature of much of the Qur'an has enabled the emergence of new meanings and interpretations. At any time, religious traditions are both a product and a process, and almost always consist of several interpretations that share a 'family resemblance' in the Wittgenstein sense of the term. What justifies calling them part of the same tradition is their sense of common origin as well as continued references to shared texts, symbols, personalities, practices or beliefs. This interpretive exercise has led to the diversity of doctrines, beliefs and rituals, all sharing a common sense of origin and reference to their sacred book and Prophet Muhammad. Iranian scholar Abdol Karim Soroush summarises the resulting historical experience of Muslims:

Muslim intellectuals still talk about Islam as if it were a simple, unified entity; a singular object. But in reality, the history of Islam like the history of other religions such as Christianity, is fundamentally a history of different interpretations. Throughout the development of Islam there have been different schools of thoughts and ideas, different approaches and interpretations of what Islam is and what it means. There is no such thing as a "pure" Islam that is outside the process of historical development. The actual lived experience of Islam has always been culturally and historically specific and bound by the immediate circumstances of its location in time and space (quoted in Noor 2002, p 25).

It is thus not a surprise that when educators look back at Muslim past to derive the best of the tradition, they come up with very different outcomes. 
We can thus propose that religious traditions, and thus the very best of these traditions, are not a given. There is, in other words, 'no essence of the tradition' that can be passed on to the next generation. Rather, religious traditions are kept alive through the enmeshing of believers' agency, and the received interpretations, resulting in the production of new meanings and ever changing conceptions of the essence of the tradition; even though the newness in many cases might be hard to notice.

The idea that sacred texts require human interpretative exercise is by no means only a modern or Western idea - as some may claim to dismiss it - but its seeds at least, can already be found in Muslim history.

In the very first century of Muslim history, the question of post-Prophetic authority became extremely important. The question was raised in its most intense form by the Khawarij, a group that broke off from the supporters of the fourth Muslim Caliph Hazarat 'Ali (d. 661) when he accepted arbitration in his battle with a rival claimant to the Caliphate, Mu'awiyya (d. 680). The Khawarij claimed that all sovereignty belongs to God and that Hazarat 'Ali had betrayed God by accepting human arbitration. Historians have recorded Hazarat 'Ali's responses to these claims which are of relevance to the point being made here. In one report, Hazarat'Ali laid a large copy of the Qur'an in front of a group of people and asked the Qur'an to speak to them, i.e. give God's judgment. The people gathered around Hazarat 'Ali exclaimed, "What! 'Ali, do you mock us? It is but paper and ink, and it is we (human beings) who speak on its behalf."' At this point, Hazrat 'Ali stated, "the Qur' an is written in straight lines between two covers. It does not speak by itself. It needs interpreters, and the interpreters are human beings"' (Abou El Fadl 2001, p 24).

\section{The way forward: pedagogical implications}

What are the implications of this variety for Muslim schools as they seek to make a contribution to the common good? There is no internal religious criterion by which a particular understanding of Muslim tradition can be objectively considered as the best tradition or the essence of a tradition. Schools can therefore build their own understanding of the very best of tradition. A school's understanding will depend on which particular denomination it belongs to and how its leaders understand Muslim tradition. Thus, we should not be surprised that different Muslim schools will have different views on what is the best in the tradition. 
Secondly, faith schools often claim that their main objective is educational, that is they wish to provide students with high quality education. If so, then from an educational point of view, a child can be regarded as having a right to learn about as much of the tradition as possible and not just a single part of the tradition that the school leaders or parents belong to. From this perspective, the best of the tradition is in fact the understanding of tradition as an open-ended process, which the child not only inherits but is also able to critically engage with; rejecting or taking it forward as s/he may eventually decide.

But this consideration of educational aim and child's right requires a shift in the way schools understand the very idea of religion, and in this case, Islam. Muslim faith schools, along with other faith schools, as well as religious education in secular schools, operate on the basis of religion as a finished product, a reified object or an abstract idea made into something concrete - which provides guidance, and about which students have to acquire an inert body of knowledge. The recently proposed syllabus for religious education in the UK, which was made public for consultation, also takes this conception of religion for granted. ${ }^{4}$ As noted above, such a conception is untenable in light of our historical knowledge. If faith schools are to be justified in the manner proposed by Pring, the most important shift required is in the conception of the very idea of religion that underpins these schools.

To induct children into the very best of a tradition is not about handing them some timeless doctrines, values, beliefs and moral commands. That would be an injustice to both the tradition and to children. It would take religious tradition to be ahistorically given. It is rather about helping children see the interpretive nature of their religion, to nurture in them an understanding of historicity and the diversity of beliefs, institutions, values and rituals. It is to encourage children to see themselves as the latest link in a chain, a work-in-progress, with agency to interpret the tradition for themselves. In short, it is to make children both inheritors and creators of tradition.

Let me give a concrete example to bring out the implication of the interpretive approach. Among the topics often discussed in Muslim schools is the relationship between science and

\footnotetext{
${ }^{4}$ Available at: https://www.gov.uk/government/consultations/gcse-and-a-level-reform-religious-studies. Accessed, January 17, 2015.
} 
Islam. Typically, the pedagogical approach to this topic is to present to students a selection of Qur'anic verses and Prophetic sayings which encourage the use of reason and pursuit of knowledge. This is followed by a list of Muslim scientists and their activities. Finally, some case studies are presented to show how Muslim scientific contributions impacted medieval European scholarship. The aim of this approach is to instil among children a positive attitude towards science and to show them a religious endorsement of science.

The approach proposed in this paper would lead to a different pedagogical engagement with the topic of science and Islam. It would begin by helping students recognise that there is no single way in which the relationship between science and Islam was understood in Muslim contexts. Rather, we have a spectrum of views ranging from those for whom science is a form of worship as it enables humans to learn about God's creation, to those who advocate separate spheres for science and Islam, along the lines of Stephen Jay Gould's notion of 'nonoverlapping magisterial.' While there are scientists who subscribe to religious teachings, there are also many who do not, including several scientists in the past, who did not. Muhammad ibn Zakariya Razi (d. 925) is perhaps the best example of such men of science, a physician in this case, who did not subscribe to religious teachings. Others, such as Ibn Sina (d.1037) held unorthodox views about key Muslim beliefs such as prophecy and the hereafter, so much so that a prominent scholar al-Ghazali (d. 1111) declared him (and others) heretics. There were those who saw complementarity of reason and revelation, but also those who believed that reason must be subordinate to revelation. Thus, it is important to convey to students that while science was certainly highly valued and Muslim cultures made significant contributions to it, there was no unanimity about the understanding of the relationship between science and religions. It is through being introduced to this range, that students would be able to see that there is no readymade answer to the question of Islam's relationship with science, rather, that they would need work it out for themselves.

T S Eliot in Tradition and the Individual Talent writes, 'If the only form of tradition, of handing down, consisted in following the ways of the immediate generation before us in a blind or timid adherence to its successes, "tradition" should positively be discouraged' (Eliot 1921). This observation seems particularly true for an education that seeks to induct children into a tradition. The diverse ways in which scholars have understood what the Islamic tradition has to offer educationally - all the while referring to the same body of texts, institutions and personalities in Muslim history - should alert us to the fact that the best in a tradition is not a 
given, a concrete reality simply to be observed and drawn upon. It is rather, an outcome of the fusion of horizons between educators and the tradition. It is as much an act of interpretation as a matter of historical reality. Every fusion modifies the tradition, if ever so slightly, and fresh meanings are created. To quote Eliot again, the past is 'altered by the present as much as the present is directed by the past'.

The very best of a tradition is that it is alive, and that it 'cannot be inherited, and if you want you must obtain it by great labour' (Eliot, 1921) - labour that involves criticality, agency and interpretive freshness. From the point of view of education, which is what ultimately many faith schools claim to be involved in, to pass on the tradition is to help children do this act of labour and thereby become responsible for its future and fate.

\section{Conclusion}

I began with Pring's idea of the 'very best of different traditions' acting as a springboard to explore his proposed justification for faith schools. I then considered how various Muslim educationists have understood the very best in Muslim tradition which they wanted to be implemented through Islamic education in faith schools. It emerged that the understanding of the very best in Muslim tradition has varied over decades and across thinkers. This led to the realisation that the 'very best of different traditions' is not a given. It is not out there to be found and passed on through education. Rather, it is an interpretation shaped by the believer's historical situation, by the fusion of agency and structure. An education inducting students into the very best of tradition is not about passing on a set of beliefs, values, practices and doctrines. It is rather about helping students see the role of human agency in the making of tradition and thereby empowering them to use their own agency in carrying the tradition forward - not as a heritage or inheritance but as a living organism. 


\section{Bibliography}

Abbas, T. (2011). Islam and Education. London: Routledge.

al-Attas, S. M. (Ed.). (1979). Aims and Objectives of Islamic Education. Jeddah: Hodder and Stoughton.

al-Faruqi, I. (1995). Islamisation of knowledge: General principles and work plan. Herndon, Va.: International Institute of Islamic Thought

Ameli, R. S., Azam, A., \& Merali, A. (2005). Secular or Islamic? What Schools do British Muslims want for their Children? London: The Islamic Human Rights Commission.

Ansari, H. (2004). The 'Infidel' within: Muslims in Britain since 1800 London: C. Hurst \& Co.

al-Ghazali. (1953). The faith and practice of al-Ghazali (W. M. Watt, Trans.). London:

George Allen and Unwin.

Ashraf, S. A. (1988). The conceptual framework of education: The Islamic perspective.

Muslim Education Quarterly, 5(2), 8-18.

Cook, Bradley (2010) Classical Foundations of Islamic Educational Thought. Provo, Utah:

Brigham Young University Press.

Eliot, T.S (1921) “Tradition and Individual Talent" in The Sacred Wood: Essays on poetry and criticism. New York: Alfred A Knopf.

Ernst, C. (2004) Following Muhammad. Chapel Hill: University of North Carolina Press

Fetzer, J. S. (2006). Muslims and the state in Britain, France, and Germany. Cambridge:

Cambridge University Press.

Goodman, L. E. (2003). Islamic humanism. Oxford: Oxford University Press.

Halstead, J. M. (1988). Education, Justice and Cultural Diversity: An Examination of the Honeyford Affair, 1984-5. London: Falmer.

Halstead, J. M. (1995). Voluntary apartheid? Problems of education for religious and other minorities in democratic societies. Journal of Philosophy of Education, 29(2), 257-272. Hewitt, I. (1996). The Case for Muslim Schools. Issues in Islamic Education. London: the Muslim Educational Trust.

Khan-Cheema, A. (1984). Islamic Education and the Maintained School System. Muslim Education Quarterly, 2(1), 5-15.

Kurzman, C. (2002). Modernist Islam, 1840-1940: A Sourcebook. Oxford: Oxford University Press.

Makdisi, G. (1990). The rise of humanism in classical Islam and the Christian West with special reference to scholasticism. Edinburgh: Edinburgh University Press. 
MacEoin N, D. (2009) Music, Chess and Other Sins: Segregation, Integration, and Muslim Schools in Britain. London: Civitas: Institute for the Study of Civil Society.

Merry, M.S. (2007) Culture, Identity and Islamic Schooling: A Philosophical Approach. New York: Palgrave Macmillan.

Mustafa, B. (1999) Education for Integration: Case Study of a British Muslim High School for Girls. Journal of Muslim Minority Affairs, 19 (2), 291-298.

Nasr, S. H. (1985). The Islamic Philosophers' Views on Education. Muslim Education Quarterly, 2(4), 5-16.

Panjwani, F. (2009). Rethinking the educational case for schools with Muslim religious character: Critical analysis of the conceptions of knowledge and autonomy (Unpublished D. Phil thesis). University of Oxford.

Panjwani, F (2014), "Faith-schools and the religious other: the case of Muslim schools" in J Chapman, M Reiss, S McNamara \& Y Waghid (eds), International Handbook of Learning, Teaching and Leading in Faith-Based Schools. Springer, London.

Pring, R. (2005) Faith Schools: Can they be justified? In R. Gardner, J. Cairns \& D. Lawton (eds.) Faith Schools: Consensus or Conflicts? London: Routledge Falmer, pp. 51-60 Pring, R. (2009) Can faith schools serve the common good? In G. Haydon (Ed.) Faith in Education: A Tribute to Terence Mclaughlin. Institute of Education, University of London, Rahman, F. (1982) Islam and Modernity. Chicago: University of Chicago Press. Saliba, G. (2011). Islamic Science and the Making of the European Renaissance. Massachussets: MIT Press.

Sarwar, G. (1994). British Muslims and Schools. London: The Muslim Education Trust. Sahin, A. (2013) New Directions in Islamic Education: Pedagogy and identity formation, Kube Tan, C. (2014) Reforms in Islamic education: international perspectives. London: Bloomsbury Academic

Taylor, C. (1991) Malaise of Modernity. Cambridge: Harvard University Press.

Waghid, Yusef. (2011) Conceptions of Islamic Education: Pedagogical Framings. New York: Peter Lang Publishing, Inc.

Zine, J. (2008). Canadian Islamic schools: Unravelling the politics of faith, gender, knowledge, and identity. Toronto: University of Toronto Press.

Zine, J. (2011) Safe Havens or Religious “Ghettos” In: Abbas, T. (Ed.) Islam and Education: Major Themes in Education. London: Routledge 